METALLURGY AND FOUNDRY ENGINEERING - Vol. 37, 2011, No. 1

\author{
Maria Maj*
}

\title{
ALLOWABLE STRAIN AS AN INDICATOR OF FATIGUE LIFE
}

\section{INTRODUCTION}

Structures under load changing with time often suffer failure, which occurs without any clear plastic deformation but is a consequence of cracks that appear after certain number of the changing load cycles; if this happens, the factor responsible is the fatigue of material. In practice, this term means a finite number of cycles which the material is capable of bearing until the failure occurs. The process of material damage as a result of fatigue is divided into the three main stages: crack initiation, crack propagation and final collapse. These stages are very important in the determination of fatigue life of the structural elements.

One of the main quantitative criteria of the material fatigue behaviour is the fatigue strength. It depends on many factors, which either do not affect or affect to a small extent only the static mechanical properties. For example, the quality of the specimen surface (smoothness, internal stresses, surface hardening, etc.) are of no major importance for the results of static tests, but are critical for the fatigue strength.

The conventional fatigue tests (the determination of Wohler curve) have been known as a test method for a long time. Yet, their obvious drawback is the need to use a relatively large number of the specimens, and if an appropriate number of the test stands is not available to run parallel fatigue tests at different levels of the medium stress and for different values of the maximum stress amplitude, the time of the experiments may extend to even several weeks. One of the means to eliminate this drawback is by reducing the duration of a conventional fatigue test; an alternative is to conduct studies under quasi-static loads [2,3]. Based on the results of such studies, the fatigue strength can be to evaluated as an allowable stress level, or as a stress approaching the asymptote of a Wöhler curve without the need to

* Ph.D.: Faculty of Foundry Engineering, AGH University of Science and Technology, Kraków, Poland; e-mail: mmaj@agh.edu.pl 
determine the course of this curve in a range of the stress values higher than the fatigue strength $[4,5]$.

In this publication, tests were carried out on specimens cut out from a tubing (a part of the subway tunnel lining) applying the method described in other papers $[2,5]$ and defined by the authors as a MLCF method (modified low-cycle fatigue test). Using the obtained results, the maximum allowable total true permanent strain was determined. Additionally, the strain behaviour was examined by Mathara technique on a real cast tubing and the obtained results, supported additionally with the Huber-Mises-Hencky strength hypothesis, enabled determination of the equivalent strain. Detailed examinations and a comparison of thus calculated value of the equivalent strain with the value of the allowable strain determined from a modified low-cycle fatigue test (MLCF) prove that the allowable strain can serve as an indicator of fatigue life.

\section{LOW CYCLE FATIGUE TEST (LCF AND MLCF)}

The analysis of mechanical properties in a range of the low-cycle changing loads in Coffin-Manson and Morrow's approach [1, 2, 3, 4, 5], covered also by a Polish standard [6], is known as a LCF (Low Cycle Fatigue) test method. Its essence consists in studies carried out under the conditions of symmetrically applied loads. The loading cycle is based on a tension and compression alternatively applied onto the specimen within the range of "hypercritical" stresses, i.e. above the fatigue limit, starting in most cases with the stress amplitude that will cause permanent strain of at least $0.2 \%$. Adopting such conditions leads to a reduced number of cycles responsible for the specimen failure, while the results of tests made on one specimen are represented by one point on the low-cycle fatigue strength curve (Fig. 1). Hence it follows that the results are the more accurate, the larger is the number of the specimens used in the test.

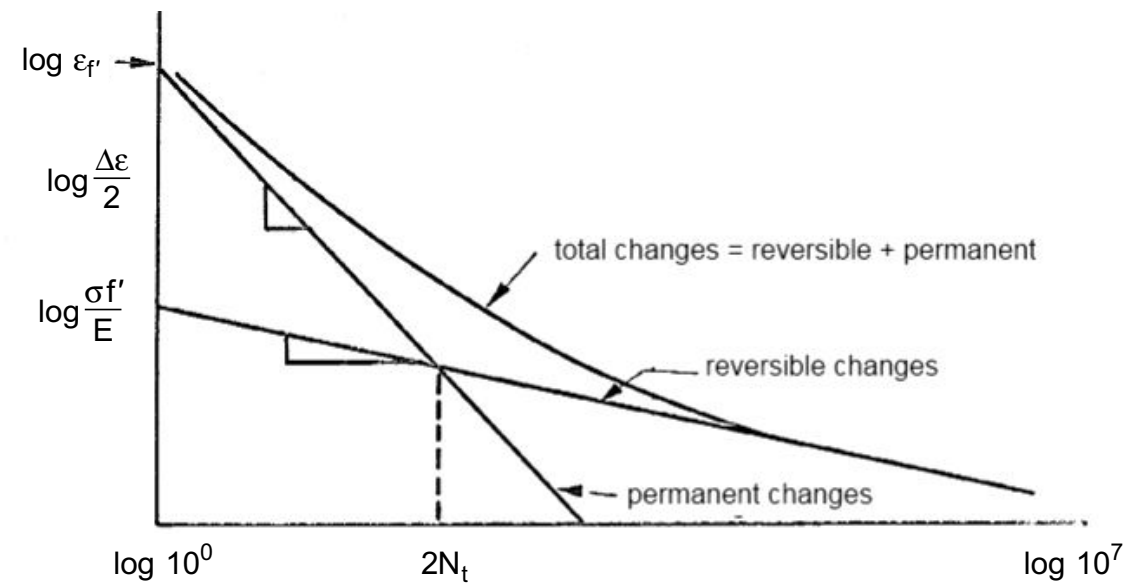

Fig. 1. Fatigue life diagram plotted in logarithmic coordinates [3] 
Practical application of the LCF test is limited to materials characterised by good plastic properties, since the whole measuring range is substantially lying well above the yield strength limit $[2,3]$. As specified by relevant standard [6], the test consists in subjecting the specimen to uniaxial changing loads (operating in a tensile-compressive mode) until failure of the specimen occurs, and in recording during the test the number of cycles and the stressstrain (force-displacement) relationship in the form of a hysteresis loop. The parameter controlled during the test is stress (force related to the specimen initial cross-section), strain (the specimen reference line), or displacement (of the loading system).

The determination by this method of the limit cycles for several values of the amplitude enables various other criteria used in the material evaluation to be determined, including the limit strain value.

According to the above mentioned researchers, the following equations can be written down:

$$
\begin{aligned}
& \sigma_{a}=\mathrm{K}^{\prime}\left(\varepsilon_{\mathrm{p}}\right)^{n^{\prime}} \\
& \sigma_{a}=\sigma_{f}^{\prime}\left(2 N_{f}\right)^{b} \\
& \varepsilon_{p}=\varepsilon_{f}^{\prime}\left(2 N_{f}\right)^{c}
\end{aligned}
$$

where:

$\sigma_{a}$ - the cycle stress amplitude,

$\sigma_{f}^{\prime}$ - the ,fatigue life coefficient” roughly equal to the tensile strength $R_{m}$,

$\varepsilon_{f}-$ the true permanent strain caused by stress $\sigma^{\prime}$,

$2 N_{f}$ - the number of loading cycles to specimen failure,

$\varepsilon_{p}$ - the permanent strain (the true strain caused by $2 N_{f}$ number of loading cycles, where: $\varepsilon_{p}=\ln \left(1+\varepsilon_{k}\right)$, and where $\varepsilon_{k}=\Delta l_{\text {permanent }} / l_{0}$,

$K^{\prime}$ - the cyclic strength coefficient,

$n^{\prime}$ - the cyclic strain hardening exponent,

$c^{\prime}$ - the fatigue ductility exponent,

$b$ - fatigue of the exponent (Basquin's coefficient).

Assuming a constant value of the modulus of elasticity $E$ (over the whole stress range up to a fatigue limit), the following equation expressing the elastic strain $\varepsilon_{e}$ can be written down:

$$
\varepsilon_{e}=\sigma_{f} / E^{*}\left(2 N_{f}\right)^{b}
$$

Assuming now that $2 n F$ equals the minimum number of cycles that the material must endure under the effect of the changing stress of an amplitude $\sigma_{a}$ equal to the fatigue limit (a „reference” number of cycles), an equation allowing for total strain $\left(\varepsilon_{c}\right)$ after this number of cycles and after any arbitrary lower number of cycles can be written down:

$$
\varepsilon_{\text {max }}=\varepsilon_{e}+\varepsilon_{f}=\sigma_{f} / E^{*}\left(2 N_{f}\right)^{b}+\varepsilon_{f}^{\prime}\left(2 N_{f}\right)^{c}
$$

$\varepsilon_{\max }-$ maximal permissible true strain in changing loads. 
Here it should be emphasized that the measurement of the above mentioned parameters in a standard low-cycle fatigue test (LCF) requires 6-10 specimens, which creates problems in the case of structurally inhomogeneous materials. On the other hand, in its modified form (the MLCF test) [2,3], this method allows the same parameters to be determined on one specimen only, as discussed extensively in other studies $[2,3,6,9]$.

The fatigue strength $Z_{g o}$ (Fig. 2), necessary for the computation of test parameters, is estimated from an experimental diagram plotted for a diverse group of materials, starting with pure metals and ending in alloys of ferrous and non-ferrous metals [2, 3].

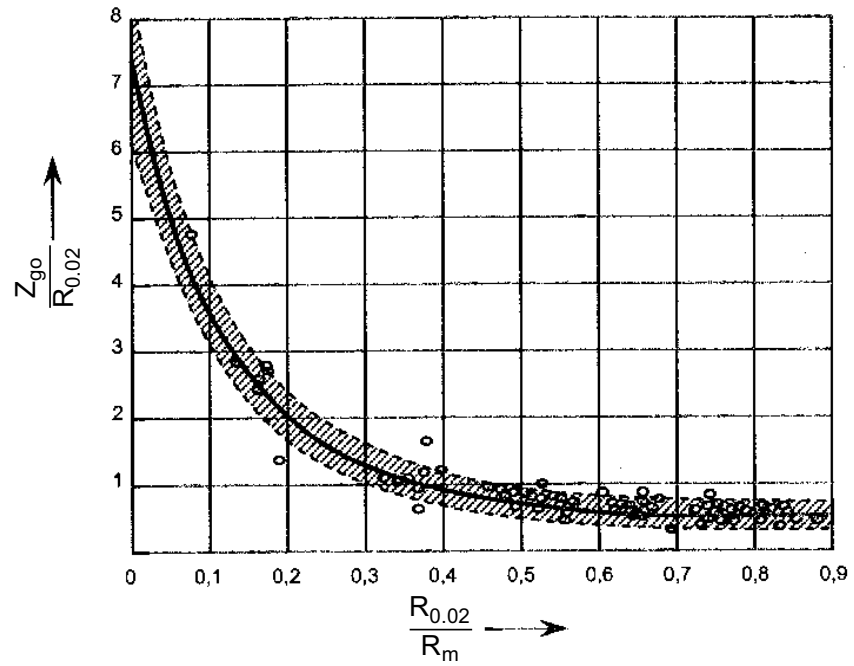

Fig. 2. The curve for fatigue strength estimation [3]

\section{TESTING OF CAST MATERIAL EFFORT}

Various effort hypotheses are formulated as theorems allowing the assessment if loading applied on a structural element and inducing in this element the state of two-or triaxial stress exceeds or not the allowable value. The values of the allowable stress $\left(\sigma_{d o p}\right)$ are established in mechanical tests carried out under a uniaxial state of stress, while the adopted effort hypothesis allows replacing the load-induced state of stress with the, so-called, equivalent stress. The energy hypothesis, or Huber-Mises-Hencky hypothesis (briefly denoted as $\mathrm{HMH}$ ), which was used in this study, adopts the pure non-dilatational strain energy as a criterion, which leads to the following expressions derived for an equivalent stress under the 3D and 2D plane stress state, respectively:

$$
\begin{aligned}
& \frac{1}{2}\left[\left(\sigma_{1}-\sigma_{2}\right)^{2}+\left(\sigma_{2}-\sigma_{3}\right)^{2}+\left(\sigma_{3}-\sigma_{1}\right)^{2}\right] \leq \sigma_{0_{3}}^{2} \\
& \sigma_{1}^{2}-\sigma_{1} \sigma_{2}+\sigma_{2}{ }^{2} \leq \sigma_{0_{3}}^{2}
\end{aligned}
$$


The use of maximum strain determined during the low-cycle fatigue test (5) requires an appropriate transformation of the conditions set out by the HMH hypothesis. Using a generalised form of Hook's law and making transformations suggested in [2], Huber hypothesis of pure non-dilatational strain can be written down as:

$$
\begin{aligned}
& \frac{1}{2(1+\mu)^{2}}\left[\left(\varepsilon_{1}-\varepsilon_{2}\right)^{2}+\left(\varepsilon_{2}-\varepsilon_{3}\right)^{2}+\left(\varepsilon_{3}-\varepsilon_{1}\right)^{2}\right] \leq \varepsilon_{0}^{2} \\
& \frac{\left(\varepsilon_{1}^{2}+\varepsilon_{2}^{2}\right)\left(1-\mu+\mu^{2}\right)+\varepsilon_{1} \varepsilon_{2}\left(4 \mu-1-\mu^{2}\right)}{\left(1-\mu^{2}\right)^{2}} \leq \varepsilon_{0}^{2}
\end{aligned}
$$

Setting the critical conditions, therefore, the knowledge of the modulus of elasticity becomes superfluous, but one should remember that in this way a simplification is made, because the above equations have been written on the assumption that the values of the modulus are equal for both the cast element and specimen. Therefore it is advisable to determine the limit strain according to formula (5) on a specimen taken from the real casting, and this is precisely what has been done in the present studies. Surely this procedure cannot guarantee that the influence of local casting heterogeneities will be totally eliminated, but if there are places in the casting of inferior quality, the strain in these areas will assume higher values which, when compared with the critical strain determined for material of higher properties, will indicate the dangerous level of deformation.

\section{TEST MATERIAL AND RESULTS}

Studies described in this article proceeded in two ways. First, using the results of fatigue tests carried out on specimens cut out from the cast tubing (Fig. 3 and Tab. 1), the selected mechanical properties presented in Table 2 were determined in accordance with the MLCF procedure. Second, the internal stresses were measured in the real cast tubing, whose schematic diagram and the distribution of strain gauge rosettes are shown in Figure 4. Tests were conducted by Mathara programme, which assumes drilling of holes at the point of intersection of the longitudinal axes of the three strain gauges forming a rosette, and in measuring thus induced strain by individual strain gauges included in the rosettes (measurements are taken before and after drilling of the holes).

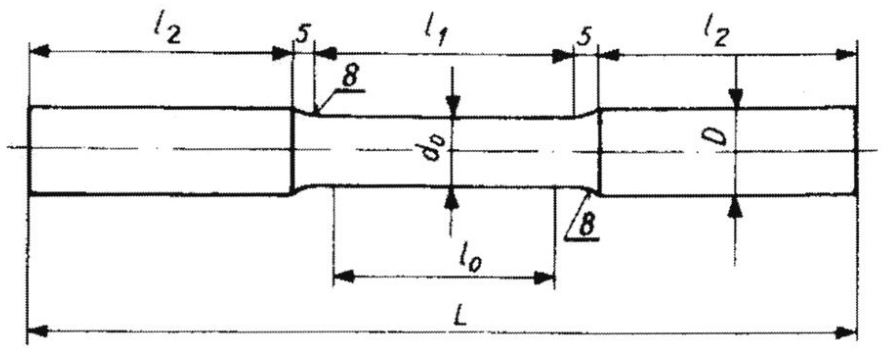

Fig. 3. Dimensions of specimens used in the currently conducted tests 
Table 1. Dimensions of specimens used in the currently conducted mechanical tests

\begin{tabular}{|c|c|c|c|c|c|c|c||}
\hline$d_{0}$ & $D$ & $l_{0}$ & $l_{1}$ & $l_{2}$ & $L$ & $D$ & $H$ \\
\hline $\mathrm{mm}$ & $\mathrm{mm}$ & $\mathrm{mm}$ & $\mathrm{mm}$ & $\mathrm{mm}$ & $\mathrm{mm}$ & $\mathrm{mm}$ & $\mathrm{mm}$ \\
\hline 8 & 10 & 40 & 45 & 30 & 125 & 12 & 16 \\
\hline
\end{tabular}

Table 2. Mechanical properties determined from fatigue tests carried out by the MLCF technique

\begin{tabular}{|c|c|c|c|c|c|c|c||}
\hline No. & $R_{m}$ & $R_{0.02}$ & $R_{0.2}$ & $Z_{g o}$ & $b$ & $c$ & $\varepsilon \cdot_{\max }$ \\
\hline $2 \mathrm{t}$ & 569.5 & 339.4 & 478.8 & 188.5 & -0.09603 & -0.44562 & 0.01069 \\
\hline $3 \mathrm{t}$ & 556.7 & 340.7 & 469.3 & 186.0 & -0.09523 & -0.53495 & 0.00899 \\
\hline $4 \mathrm{t}$ & 532.8 & 342.7 & 487.3 & 191.4 & -0.08891 & -0.34262 & 0.01156 \\
\hline $5 \mathrm{t}$ & 539.0 & 220.7 & 461.5 & 160.0 & -0.10560 & - & - \\
\hline $6 \mathrm{t}$ & 603.8 & 347.9 & 485.9 & 191.8 & -0.09959 & -0.52493 & 0.01001 \\
\hline $7 \mathrm{t}$ & 492.7 & 308.2 & 483.5 & 182.8 & -0.08612 & -0.36353 & 0.01005 \\
\hline $8 \mathrm{t}$ & 532.7 & 343.5 & 488.1 & 191.8 & -0.08872 & -0.33262 & 0.01116 \\
\hline $9 \mathrm{t}$ & 533.1 & 125.4 & 114.2 & 69.0 & -0.17765 & -0.54589 & 0.02866 \\
\hline $10 \mathrm{t}$ & 492.0 & 430.9 & 446.4 & 181.8 & -0.08650 & -0.36032 & 0.00977 \\
\hline $11 \mathrm{t}$ & 573.2 & 411.1 & 489.1 & 226.1 & -0.08079 & -0.56922 & 0.01141 \\
\hline
\end{tabular}
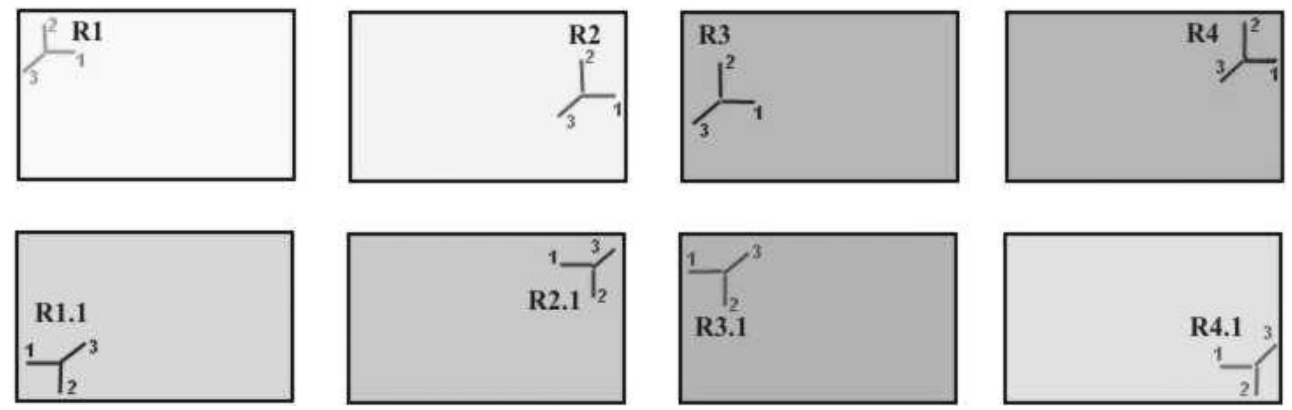

Fig. 4. Schematic diagram of tubing with the location of strain gauge rosettes

Table 3 compares the values of strain measured by individual strain gauges included in the subsequent rosettes and the calculated values of principal strain. The next step was calculation of the equivalent strain using Huber-Mises-Hencky hypothesis.

To evaluate effort, the calculated equivalent strain can be compared with the allowable strain determined from the results of the modified low-cycle fatigue test (MLCF). The strain, which is an arithmetic mean of the measurement results (Tab. 2), assumes the value 
of 0.01237 , which means that, despite an obvious heterogeneity in the values of deformation within the whole cast tubing, the critical levels have not been exceeded in any of the tubing zones.

Table 3. Strain values measured in individual rosettes compared with the calculated principal strain and equivalent strain

\begin{tabular}{|c|c|c|c|c|c|}
\hline Rosette no. & Strain gauge no. & $\varepsilon$ & $\varepsilon_{1}$ & $\varepsilon_{2}$ & $\varepsilon_{0}($ Huber $)$ \\
\hline R1 & $\begin{array}{l}1 \\
2 \\
2\end{array}$ & $\begin{array}{l}340 \\
153 \\
-76\end{array}$ & 583 & -89 & 0.000695 \\
\hline $\mathrm{R} 2$ & $\begin{array}{l}1 \\
2 \\
3\end{array}$ & $\begin{array}{c}-86 \\
-107 \\
-61\end{array}$ & 61 & -254 & 0.000313 \\
\hline R3 & $\begin{array}{l}1 \\
2 \\
3\end{array}$ & $\begin{array}{c}-70 \\
-543 \\
-40\end{array}$ & 47 & -648 & 0.000753 \\
\hline $\mathrm{R} 4$ & $\begin{array}{l}1 \\
2 \\
3\end{array}$ & $\begin{array}{l}222 \\
-75 \\
-24\end{array}$ & 251 & -104 & 0.000334 \\
\hline $\mathrm{R} 1.1$ & $\begin{array}{l}1 \\
2 \\
3\end{array}$ & $\begin{array}{c}10 \\
1 \\
9\end{array}$ & 11 & -1 & 0.000013 \\
\hline $\mathrm{R} 2.1$ & $\begin{array}{l}1 \\
2 \\
3\end{array}$ & $\begin{array}{l}-106 \\
-74 \\
-94\end{array}$ & -74 & -106 & 0.000131 \\
\hline R3.1 & $\begin{array}{l}1 \\
2 \\
3\end{array}$ & $\begin{array}{l}-61 \\
-64 \\
-87\end{array}$ & -38 & -87 & 0.000099 \\
\hline $\mathrm{R} 4.1$ & $\begin{array}{l}1 \\
2 \\
3\end{array}$ & $\begin{array}{c}19 \\
36 \\
3\end{array}$ & 53 & 2 & 0.000060 \\
\hline
\end{tabular}

\section{CONCLUSIONS}

1. The use of modified low-cycle fatigue test (MLCF) enables precise determination of the maximum limit strain, which can be regarded as equivalent to the maximum allowable strain, and hence can serve as a fatigue life criterion for the engineering material or structural element. It can replace the allowable stress and make a criterion far easier in determination because measured directly, while the determination of stress requires complicated calculations.

2. The analysis of the results of the tensometric measurements of a cast tubing has proved that equivalent strain is comparable with the allowable strain obtained during the test with reduced number of cycles.

The study was made under project no. 10.10.170.345 


\section{REFERENCES}

[1] Kocańda St., Kocańda A.: Niskocyklowa wytrzymałość zmęczeniowa metali, PWN, Warszawa 1989

[2] Maj M.: Kryteria wytrzymałości eksploatacyjnej odlewów żeliwnych w oparciu o właściwości mechaniczne tworzyw, AGH Wydz. Odlewnictwa, Kraków 1984 (Ph.D. thesis, not published)

[3] Karamara A.: Badania materiałowe wybranych gatunków stali niskostopowej w zakresie niskocyklicznych obciążeń zmiennych, Kraków, 1980 Z-5216/79

[4] Kocańda St.: Zmęczeniowe niszczenie metali, WNT, Warszawa 1978

[5] Socie D.F., Mitchell M.R., Caulfield E.M.: Fundamentals of Modern Fatigue Analysis. A Report of the Fracture Control Program, College of Engineering. University of Illinois Urbana, Illinois 61801, April, 1977. Revised January 1978

[6] PN-84/H-04334: Badania niskocyklowego zmęczenia metali

[7] Maj M.: Optymalizacja programu badań niskocyklowej próby zmęczeniowej, AGH, Wydz. Odlewnictwa, 2005, sprawozdanie z pracy własnej nr 10.10.170.34

[8] Karamara A.: Wyznaczanie wytrzymałości postaciowej odlewów na podstawie granicy akomodacji. Prace Komisji Metalurgiczno-Odlewniczej, PAN - Oddział w Krakowie, Metalurgia, 17 (1971), 7

[9] Maj M.: Zastosowanie zmodyfikowanej, niskocyklowej próby zmęczeniowej do wyznaczania właściwości mechanicznych żeliwa ADI w temperaturze pokojowej i podwyższonej, AGH, Wydz. Odlewnictwa, Kraków 2005, spraowzdanie do projektu badawczego nr 4T8B00625

Received

January 2011 